\title{
The Application of Compost Extract Enriched with Eggshell Flour on the Growth and Production of Sweet Corn Plants (Zea mays saccharata)
}

\author{
Kasman $^{1^{*}}$, Saiful Darman ${ }^{2}$, Mahfudz $^{2}$, Uswah Hasanah ${ }^{2}$, Amirudin $^{3}$, Ramli $^{4}$
}

\author{
${ }^{1}$ Agrotechnology Study Program, College of Agricultural Sciences Mujahidin Toli-Toli, Indonesia \\ ${ }^{2}$ Agrotechnology Study Program, Faculty of Agriculture, Tadulako University, Indonesia \\ ${ }^{3}$ Agrotechnology Study Program, Faculty of Agriculture, Bosowa Makassar University, Indonesia \\ ${ }^{4}$ Agrotechnology, Faculty of Agriculture, University of Tadulako, Palu, Indonesia
}

DOI: $10.36347 /$ sjavs.2022.v09i02.002

| Received: 16.01.2022 | Accepted: 19.02.2022 | Published: 26.02.2022

*Corresponding author: Kasman

Agrotechnology Study Program, College of Agricultural Sciences Mujahidin Toli-Toli, Indonesia

Abstract

Original Research Article

The aim of this study was to investigate the application of compost extract enriched with eggshell flour on the growth and production yield of sweet corn plants. This research was conducted from July to September 2021 at the Academic Farm of the Faculty of Agriculture, Tadulako University, Central Sulawesi Province, Indonesia. This study used a randomized block design with a factorial pattern. The first factor was the time of eggshell flour addition consisting of 5 treatments, i.e., W1 = 1 week after planting (WAP); W2 = 2 WAP; W3 = 3 WAP; W4 = 4 WAP; W5 = 5 WAP. The second factor was corn compost extract application consisting of 2 treatments, i.e., A1 = application on the soil; A2 = application on the plants. Therefore, 10 treatment combinations were obtained, and each treatment combination was repeated 3 times to obtain 30 experimental units. The results showed that there was no interaction effect between the application of corn compost extract and the time of eggshell flour addition in all measured parameters. The treatment that resulted in better growth and yield of sweet corn was the combination treatment of 1 WAP and application through the soil on all measured parameters, The time of eggshell flour addition of 1 WAP gave a better effect on the growth and yield of sweet corn plants on the parameters of plant height at 28 days after planting (DAP), stem circumference at 49 DAP, length and diameter of the corncob with husks, and weight of the corncob without husks, and Application of corn compost extract treatment through the soil gave a better effect on the growth of sweet corn plants on the parameters of plant height at 28 DAP, stem circumference at 42 and 49 DAP and number of leaves at 14 DAP.

Keywords: Compost extract, Eggshell flour, Corn, stem circumference, plant height.

Copyright $($ C 2022 The Author(s): This is an open-access article distributed under the terms of the Creative Commons Attribution 4.0 International License (CC BY-NC 4.0) which permits unrestricted use, distribution, and reproduction in any medium for non-commercial use provided the original author and source are credited.

\section{INTRODUCTION}

Corn is the second staple food after rice in Indonesia. Corn is specifically a food plant that is very beneficial for human and animal life (Trumbo et al., 2002); (Siyuan et al., 2018). Based on the order of staple foods in the world, corn ranks third after wheat and rice. Until now, corn plants are used by the community in various forms of presentation, such as: corn flour (maizena), corn oil, food ingredients (Gwirtz \& Garcia-Casal, 2014), as well as animal feed and others. Sweet corn is especially preferred in the form of boiled or grilled corn. Sweet corn has a sweet taste because the sugar content is $5-6 \%$ which is higher than ordinary corn with a sugar content of $2-3 \%$ (Sirajuddin, 2010). However, the people of Central Sulawesi mostly consume it as boiled and roasted corn. Sweet Corn is a type of corn that has just been recognized in Indonesia.
Sweet corn is increasingly popular and widely consumed because it has a sweeter taste than ordinary corn and has a shorter production life (early), so it is very good for cultivation (Rahmi and Jumiati, 2007).

Central Sulawesi Province is one of the corn production centers in Indonesia. The development of corn in the last 5 years showed an increase in production with an average growth rate of $0.35 \%$. In 2010 , the production yield was only 171,180 tons and increased to 197,488 tons in 2011. The increase in production was due to the increased use of high yielding varieties and planting area (BPTP Central Sulawesi, 2011). The market demand for sweet corn continues to increase and the large market opportunity has not been fully utilized by farmers and entrepreneurs due to various constraints. In general, agricultural soils 
cannot provide all the nutrients required by plants in a short time, so fertilization is necessary. Fertilization aims to replace nutrients that are transported at harvest or lost due to erosion and leaching, as well as continuous land use (Lidar and Surtinah, 2012).

One of the organic fertilizers that can be used is the extract from various types of agricultural waste compost such as rice straw, corn straw, and banana plant waste extracts. Compost extract is one type of organic fertilizer that contains macro and micro nutrients. In addition, compost extract has advantages in its use, e.g., it can improve plant health, provide instant nutrient solutions that can be immediately absorbed by plants, improve soil structure, can be used as pest and disease controls, and improve the environment so as to reduce chemical residues (Suganthi \& Jayanandhan, 2015). The effectiveness of organic extracts is largely determined by the quality and type of organic matter and the technology used in the fermentation process. Consequently, extracts derived from rice straw waste, banana tree trunk waste and corn plant waste will have different impacts on the growth of sweet corn plants and the physical, chemical and biological properties of the soil. Periodic use of compost extracts will provide a supply of macronutrients $\mathrm{N}, \mathrm{P}, \mathrm{K}, \mathrm{Ca}, \mathrm{Mg}, \mathrm{S}$, and micronutrients $\mathrm{Fe}, \mathrm{Zn}, \mathrm{Mn}$, and $\mathrm{Cu}$, as well as being able to suppress the growth and development of plant pathogenic microbes (Dimkpa \& Bindraban, 2016); (Begum et al., 2019).

Compost extract combined with eggshell waste was expected to be a new innovation in the form of a product that has a dual function, i.e., as a fertilizer and also as an organic pesticide with application techniques given to plants, especially sweet corn plants from food processing waste such as eggshells. Eggshells generally consist of water and dry matter. Of the total dry matter available, eggshells contain mineral elements and protein (Ray et al., 2017). The treatment of chicken eggshell powder can significantly affect the height and growth of Japanese frangipani (Adenium obesum), so that eggshell waste can be used as fertilizer to obtain calcium elements and neutralize soil acidity levels (Syam et al., 2014). Therefore, this research was conducted to investigate the application of agricultural waste compost extract combined with eggshell flour waste on the growth and production yield of sweet corn plants. This study aimed to investigate the effects of compost extract enriched with eggshell flour application on the growth and production yield of sweet corn.

\section{MATERIALS AND METHODS \\ Research Time and Location}

This research was conducted from July to September 2021 at the Academic Farm of the Faculty of Agriculture, Tadulako University, Central Sulawesi Province, Indonesia.

\section{Equipment and Materials}

The machines and equipment used in this study were tractors, hoes, machetes, boards, shovels, hoses, sprinklers, measuring cups, sprayers, scissors, 50 L buckets, meters, calipers, a scale, a camera, filter papers and writing tools, while the materials used were sweet corn bonanza F1 seeds, corn plant waste, EM-4, granulated sugar, and mashed egg shells.

\section{Research Design}

This study was designed using treatments according to the factorial pattern in a randomized block design with a complete combination of two factors. The two factors studied were as follows. The first factor was the time of eggshell flour addition (W) consisting of 5 treatments, i.e., $\mathrm{W} 1=1$ week after planting (WAP); W2 = 2 weeks after planting; $\mathrm{W} 3=3$ weeks after planting; $\mathrm{W} 4=4$ weeks after planting; $\mathrm{W} 5=5$ weeks after planting. The second factor was corn compost extract application (A) consisting of 2 treatments, i.e., $\mathrm{A} 1=$ application on the soil (by pouring on the soil around the plant); $\mathrm{A} 2$ = application on the plants (by spraying on the plants).

\section{Experiment Implementation Compost Extract Production}

The compost extract production was started with the compost making first. First, the corn plant waste that was cut into pieces and was put into a $50 \mathrm{~L}$ bucket. The EM-4 and sugar were dissolved into the water with a ratio of 1:1:50 (1 cup of EM-4 + 1 cup of sugar +50 cups of water, using a $200 \mathrm{ml}$ cup), then the solution was stirred until the sugar dissolved. After the sugar was completely dissolved, the organic materials were added into the bucket, then the EM-4 solution was poured slowly into the dough evenly, and the dough was covered for 7 days. The compost produced was extracted by a biological extraction process, which was performed by mixing cooked organic compost with water (1:5) of a part bokashi and 5 parts water. Then, it was transferred in a fermentation container under aerobic conditions for 8 days of fermentation. After the fermentation was completed, the compost was filtered using a $0.45 \mu \mathrm{m}$ sieve to obtain the fermented compost extract.

\section{Eggshell Flour Preparation}

The eggshell flour preparation was started with washing the eggshell and then drying it. The eggshells were then ground and the eggshell flour was sifted using a fine sieve with a diameter of $24 \mathrm{~cm}$.

\section{Land Preparation}

Soil tillage was performed one week before planting by hoeing, loosening and leveling. Beds with 30 plots of 3 (three) replications were arranged with the distance between replications was $50 \mathrm{~cm}$, while the distance between the plots was $50 \mathrm{~cm}$. The bed served 
to regulate the drainage channel. The beds were made with a size of $2 \times 3 \mathrm{~m}$ and a height of $20-30 \mathrm{~cm}$.

\section{Planting}

Planting was conducted by tugal method (making a planting hole) with a depth of $2-3 \mathrm{~cm}$. Then 2 seeds of sweet corn Bonanza F1 were put with a spacing of $45-70 \mathrm{~cm}$ and a plant population of 16 plants. After that, the planting hole was covered with soil and then watered, so that soil moisture was maintained.

\section{Fertilization}

Fertilization was a treatment adapted to the research design in the field by the application of corn compost extract at $72 \mathrm{~mL} / \mathrm{bed}$ and the addition of eggshell flour at $128 \mathrm{~g} / \mathrm{bed}$.

\section{Plant Maintenance}

Plant maintenance included watering every morning and evening depending on the soil moisture. Weeding and mulching were performed simultaneously, depending on local environmental conditions and were carried out when weeding plants began to grow and competed for food or nutrients. Control of plant pests and diseases was performed with attention to crop conditions.

\section{Plant Harvest}

Sweet corn began to flower after 50 days. Sweet corn that was ready to harvest was usually marked by the leaves and stems of the plant starting to dry and turning brown. Harvesting was performed after the plant was 70-85 days old.

\section{Observations and Measurement Parameters}

Observations and measurement parameters included 1) Plant height: sample plants were measured from the soil surface to the top of the leaf. Measurements were made at the ages of 14, 21, 28, 35, 42, and 49 DAP; 2) Stem circumference: all plants were measured $5 \mathrm{~cm}$ from the soil surface at the ages of 14 , 21, 28, 35, 42, and 49 DAP; 3) Number of leaves: the number of fully formed leaves was counted at the age of 14, 21, 28, 35, 42, and 49 DAP; 4) Corncob length (cm): the length of the corncob with husks was observed by measuring it from the base to the tip of the corn using a tape measure; 5) Corncob diameter (cm): the diameter of the corncob with husks was measured in the middle of the cob using a caliper, while the diameter of the cob without husks was measured at the center of the cob that had been peeled and measured using a caliper; 6) Corncob weight (g): the weight of the corncob with husks and the weight of the cob without husks was measured using a scale. Production yield was calculated as tons/ha of sweet corn.

\section{Data analysis}

Measurement data were analyzed using the Analysis of Variance (ANOVA) with the F test of 5\% and $1 \%$. If the results showed a significant effect of treatments, then the analysis was continued with a further Tukey's HSD test of 5\% to determine the differences between treatments.

\section{RESULTS AND DISCUSSION Plant Height (cm)}

Table 1 showed that the tallest sweet corn plant height at the age of 28 DAP was obtained in treatment W4 of $91.84 \mathrm{~cm}$, which was different from treatment W2, but not different from other treatments. Meanwhile, the shortest plant height was obtained in treatment W2 of $76.04 \mathrm{~cm}$, which was different from treatment W4 but not different from other treatments.

Table 1: Average Plant Height (cm) of Sweet Corn at Different Times of Eggshell Flour Addition

\begin{tabular}{|l|l|l|l|}
\hline Parameter & Treatments & Average plant height (cm) & HSD Test 5 \% \\
\hline & W1 & $88.81^{\mathrm{ab}}$ & \\
\hline & W2 & $76.04^{\mathrm{a}}$ & \\
\hline A (28 DAP) & W3 & $85.27^{\mathrm{ab}}$ & 15.66 \\
\hline & W4 & $91.84^{\mathrm{b}}$ & \\
\hline & W5 & $78.07^{\mathrm{ab}}$ & \\
\hline & W1 & $9.36^{\mathrm{ab}}$ & \\
\hline & W2 & $8.65^{\mathrm{a}}$ & 0.74 \\
\hline B (49 DAP) & W3 & $9.33^{\mathrm{ab}}$ & \\
\hline & W4 & $9.07^{\mathrm{ab}}$ & \\
\hline & W5 & $9.40^{\mathrm{b}}$ & \\
\hline
\end{tabular}

Note: $\mathrm{W}=$ time in weeks, the numbers in rows $(\mathrm{a}, \mathrm{b})$ followed by the same letter were not significantly different at Tukey's HSD test of 5\% level, A: Average Plant Height (cm), B: Average Plant Stem Circumference $(\mathrm{cm})$

Table 1 showed that the highest stem circumference of sweet corn at the age of 49 DAP was obtained in treatment W5 of $9.40 \mathrm{~cm}$, which was different from treatment W2, but not different from other treatments. Meanwhile, the smallest stem circumference was obtained in treatment W2 of 8.65 $\mathrm{cm}$, which was different from treatment W5, but not different from other treatments.

The results (Table 2) showed that the tallest sweet corn plant height at the age of 28 DAP was obtained in treatment A1 of $90.68 \mathrm{~cm}$, which was 
different from treatment A2. Meanwhile the shortest plant height was obtained in treatment $\mathrm{A} 2$ of $77.32 \mathrm{~cm}$, which was different from treatment A1.

Table 2: Average Plant Height $(\mathrm{cm})$ of Sweet Corn at Different Corn Compost Extract Applications

\begin{tabular}{|l|l|l|l|}
\hline Parameter & Treatments & Average plant height $(\mathbf{c m})$ & HSD Test 5 \% \\
\hline \multirow{2}{*}{ A (28 DAP) } & A1 & $90.68^{\mathrm{b}}$ & 10.87 \\
\hline & A2 & $77.32^{\mathrm{a}}$ & \\
\hline \multirow{2}{*}{ B (42 DAP) } & A1 & $9.05^{\mathrm{b}}$ & 0.73 \\
\hline & A2 & $8.21^{\mathrm{a}}$ & \\
\hline \multirow{2}{*}{ B (49 DAP) } & A1 & $9.48^{\mathrm{b}}$ & 0.51 \\
\hline & A2 & $8.85^{\mathrm{a}}$ & \\
\hline \multirow{2}{*}{ C (14 DAP) } & A1 & $4.18^{\mathrm{b}}$ & 0.50 \\
\hline & A2 & $3.62^{\mathrm{a}}$ & \\
& A2 & \\
\hline
\end{tabular}

Note: A: Average Plant Height $(\mathrm{cm})$, B: Average Plant Stem Circumference $(\mathrm{cm})$ C: Average Number of Leaves $(\mathrm{cm})$ the numbers in rows $(a, b)$ followed by the same letter were not significantly different at Tukey's HSD test of 5\% level

Table 2 showed that the highest stem circumference of sweet corn at the age of 42 DAP was obtained in treatment A1 of $9.05 \mathrm{~cm}$, which was different from treatment A2. Meanwhile, the smallest stem circumference was obtained in treatment A2 of $8.21 \mathrm{~cm}$, which was different from treatment A1. At the age of 49 DAP, the highest stem circumference was obtained in treatment A1 of $9.48 \mathrm{~cm}$, which was different from treatment A2. Meanwhile, the smallest stem circumference was obtained in treatment A2 of $8.85 \mathrm{~cm}$, which was different from treatment A1. Table 2 showed that the highest number of leaves of sweet corn at the age of 14 DAP was obtained in treatment A1 of 4.18 blades, which was different from treatment A2. Meanwhile, the lowest number of leaves of sweet corn was obtained in treatment A2 of 3.62 blades, which was different from treatment A1.

\section{Length of the Corncob with Husks (cm)}

Table 3 showed that the longest corncob with husks length of sweet corn was obtained in W1 treatment of $38.83 \mathrm{~cm}$, which was different from treatment $\mathrm{W} 4$, but not different from other treatments. Meanwhile, the shortest length was obtained in treatment W4 of $29.92 \mathrm{~cm}$, which was different from treatment $\mathrm{W} 1$, but not different from the other treatments. Table 3 showed that the largest diameter of the corncob with husks was obtained in treatment $\mathrm{W} 1$ of $7.03 \mathrm{~cm}$, which was different from treatment W4, but not different from other treatments. Meanwhile, the smallest diameter was obtained in treatment W4 of 5.86 $\mathrm{cm}$, which was different from treatment $\mathrm{W} 1$, but not different from other treatments.

Table 3: Average Length, Diameter of the Corncob with Husks (cm) and Weight of the Corncob without Husks (g) of Sweet Corn at Different Times of Eggshell Flour Addition

\begin{tabular}{|l|l|l|}
\hline Treatments & Parameter & HSD test 5 \% \\
\hline & Lenght $(\mathrm{cm})$ & \\
\hline W1 & $38.83^{\mathrm{b}}$ & \\
\hline W2 & $31.38^{\mathrm{ab}}$ & \\
\hline W3 & $31.00^{\mathrm{ab}}$ & 8.64 \\
\hline W4 & $29.92^{\mathrm{a}}$ & \\
\hline W5 & $30.90^{\mathrm{ab}}$ & \\
\hline & Diameter $(\mathrm{cm})$ & \\
\hline W1 & $7.03^{\mathrm{b}}$ & \\
\hline W2 & $6.30^{\mathrm{ab}}$ & 0.99 \\
\hline W3 & $6.30^{\mathrm{ab}}$ & \\
\hline W4 & $5.8692^{\mathrm{a}}$ & \\
\hline W5 & $6.37^{\mathrm{ab}}$ & \\
\hline & Weight of the Corncob without Husks $(\mathrm{g})$ & \\
\hline W1 & $400.21^{\mathrm{b}}$ & \\
\hline W2 & $333.46^{\mathrm{ab}}$ & 102.34 \\
\hline W3 & $326.63^{\mathrm{ab}}$ & \\
\hline W4 & $310.85^{\mathrm{ab}}$ & \\
\hline W5 & $293.95^{\mathrm{a}}$ & \\
\hline
\end{tabular}

Note: The numbers in rows $(a, b)$ followed by the same letter were not significantly different at Tukey's HSD test of 5\% level 
Table 3 showed that the heaviest weight of the corncob without husks was obtained in treatment W1 of $400.21 \mathrm{~g}$, which was different from treatment W5, but not different from other treatments. Meanwhile, the lightest weight was obtained in treatment W5 of 293.95 $\mathrm{g}$, which was different from treatment $\mathrm{W} 1$, but not different from other treatments.

The results showed that there was no interaction effect between corn compost extract and the time of eggshell flour addition in all measured parameters, including plant height, stem circumference, number of leaves, length of the corncob with husks, diameter of the corncob with husks, diameter of the corncob without husks, weight of the corncob with husks, and weight of the corncob without husks. It is suspected that each treatment, both the time of eggshell flour addition and corn compost application, did not affect each other, so that there was no interaction between the two treatments. Plant growth and production will be better if the factors that affect growth are balanced and provide benefits (Carolina Feitosa de Vasconcelos \& Helena Garófalo Chaves, 2020). If the factors used are not balanced, then the expected production yield cannot be achieved. Fertilization of plants that are not in accordance with the requirements and levels of nutrients will result in disturbance to the plant growth. Good plant growth can be achieved if the nutrients required for growth and development are in available, balanced, and sufficient amounts. Although statistically there was no interaction between the two tested treatments, the treatment that gave the best growth and production yield of sweet corn was treatment $\mathrm{W} 1$ and $\mathrm{A} 1$ on all measured parameters.

The application of compost extract and time of eggshell flour addition did not have a relationship, so that they did not affect each other. This was presumably because the eggshells are not perfectly smooth, so that they were very slow to decompose and available to the plants. Compost that is not yet fully developed cannot supply the nutrients required by plants in the plant growth and production processes (Richard, 2005).

The results of the eggshell flour addition treatment that gave the best growth and yield of sweet corn were treatment W1 (1 WAP) on the parameters of plant height, stem circumference, length of the corncob with husks, diameter of the corncob with husks, and weight of the corncob without husks. It is apparent that the time of eggshells flour addition was at the appropriate phase in the absorption of nutrients needed by plants. Plants can grow well if the required nutrients are sufficiently available and can be absorbed by plants (Cannon et al., 2021). Plants need N, P, and K which are essential nutrients to be able to grow well (Li et al., 2019). These nutrients play a very important role in plant growth in general in the vegetative phase.
In the transition from the vegetative to the generative period, the macronutrient that plays a more important role is phosphorus. Phosphorus affects plant growth and development because it is present in all living plant cells that function to form nucleic acids, stimulate cell division, and help the process of assimilation and respiration (Ajmera et al., 2019). Phosphorus serves as a basic material for the formation of a certain amount of fat and accelerates the flowering and ripening of seeds or fruit (Gul et al., 2015).

The results of the corn compost extract treatment that gave better growth of sweet corn were treatment A1 (application on the soil) on the parameters of plant height, stem circumference, and number of leaves. It is suspected that the administration of corn compost to sweet corn plants is an adequate nutrient available for the plants. The availability of nutrients in sufficient and fulfilled quantities can affect plant growth (Valet \& Ozier-lafontaine, 2014). The nitrogen is needed in large quantities for every plant growth, especially shoot growth and stem and leaf development. Nitrogen is contained in chlorophyll, auxin and cytokinin hormones. Without an adequate supply of nitrogen, plant growth will be stunted and growth will be slow (Walker et al., 2001).

\section{CONCLUSIONS}

Based on the results, this study showed that there was no interaction effect between the corn compost extract application and the time of eggshell flour addition in all measured parameters. The treatment that resulted in better growth and production yield of sweet corn was the combination of 1 week after planting treatment and the application on the soil in all parameters. The time of eggshell flour addition of 1 week after planting gave a better effect on the growth and yield of sweet corn in the parameters of plant height at 28 DAP, stem circumference at 49 DAP, length of the corncob with husks, diameter of the corncob with husks, and weight of the corncob without husks. The application of corn compost extract treatment through the soil gave a better effect on the growth of sweet corn plants in the parameters of plant height at $28 \mathrm{DAP}$, stem circumference at 42 and 49 DAP and number of leaves at 14 DAP.

\section{REFFERENCES}

- Ajmera, I., Charlie Hodgman, T., \& Lu, C. (2019). An integrative systems perspective on plant phosphate research. Genes, 10(139), 1-25. https://doi.org/10.3390/genes10020139

- Begum, N., Qin, C., Ahanger, M. A., Raza, S., Khan, M. I., Ashraf, M., Ahmed, N., \& Zhang, L. (2019). Role of arbuscular mycorrhizal fungi in plant growth regulation: implications in abiotic 
stress tolerance. Frontiers in Plant Science, 10, 115. https://doi.org/10.3389/fpls.2019.01068

- Cannon, C., Gonzalez-Benecke, C., \& Wightman, M. (2021). Plant derived tissue and soil nutrient concentration for plantations of four conifer species growing under different site and vegetation management conditions. Forest Ecology and Management, $\quad 494, \quad 119300$. https://doi.org/10.1016/j.foreco.2021.119300

- Carolina Feitosa de Vasconcelos, A., \& Helena Garófalo Chaves, L. (2020). Biostimulants and their role in improving plant growth under abiotic stresses. Biostimulants in Plant Science, 1-14. https://doi.org/10.5772/intechopen.88829

- Dimkpa, C. O., \& Bindraban, P. S. (2016). Fortification of micronutrients for efficient agronomic production: a review. Agronomy for Sustainable Development, 36(1), 1-26. https://doi.org/10.1007/s13593-015-0346-6

- Gul, S., Khan, M. H., Khanday, B. A., \& Nabi, S. (2015). Effect of sowing methods and NPK levels on growth and yield of rainfed maize (Zea mays L.) Scientifica, 2015, 1-6. https://doi.org/10.1155/2015/198575

- Gwirtz, J. A., \& Garcia-Casal, M. N. (2014). Processing maize flour and corn meal food products. Annals of the New York Academy of Sciences, 1312(1), 66-75. https://doi.org/10.1111/nyas.12299

- Li, Z., Zhang, R., Xia, S., Wang, L., Liu, C., Zhang, R., Fan, Z., Chen, F., \& Liu, Y. (2019). Interactions between $\mathrm{N}, \mathrm{P}$ and $\mathrm{K}$ fertilizers affect the environment and the yield and quality of satsumas. Global Ecology and Conservation, 19, e00663.

https://doi.org/10.1016/j.gecco.2019.e00663
- Ray, S., Kumar Barman, A., Kumar Roy, P., \& Kumar Singh, B. (2017). Chicken eggshell powder as dietary calcium source in chocolate cakes. The Pharma Innovation Journal, 6(9), 1-4.

- Richard, T. L. (2005). Compost production. Sustainable Vegetable Growing, 294-301.

- Siyuan, S., Tong, L., \& Liu, R. H. (2018). Corn phytochemicals and their health benefits. Food Science and Human Wellness, 7(3), 185-195. https://doi.org/10.1016/j.fshw.2018.09.003

- Suganthi, A., \& Jayanandhan, D. (2015). Effect of tea compost on the growth of Vigna radiate ( L .) $\mathrm{R}$ - Wilczek. International Journal of Applied Research, 1(12), 968-972.

- Syam, Z. Z., Kasim, H. A., \& Nurdin, H. M. (2014). Effect of chicken egg shell powder plant growth cambodja against Japan (Adenium obesum). E-Jipbiol, 3, 9-15.

- Trumbo, P., Schllicker, S., Yates, A., \& Poos, M. (2002). Dietary refrence intakes for energy, carbohydrate, fiber, fat, fatty acids, cholesterol, protein, and amino acids. In American Dietetic Association, 102,11, 1621-1630.

- Valet, S., \& Ozier-lafontaine, H. (2014). Soil Quality and Plant Nutrition. In Sustainable Agriculture Reviews 14: Agroecology and Global Change (Vol. 14). https://doi.org/10.1007/978-3319-06016-3

- Walker, R. L., Burns, I. G., \& Moorby, J. (2001). Responses of plant growth rate to nitrogen supply: A comparison of relative addition and $\mathrm{N}$ interruption treatments. Journal of Experimental Botany, 52(355), 309-317. https://doi.org/10.1093/jexbot/52.355.309 